\title{
Comparison of N-Terminal Region of Coat Protein in Zucchini Yellow Mosaic Potyvirus Isolates
}

\author{
I. TÓBIÁS ${ }^{1}$, L. TZEKOVA², L. PALKOVICS ${ }^{2}$ and E. BALÁZS ${ }^{2}$ \\ ${ }^{1}$ Plant Protection Institute of Hungarian Academy of Sciences, Budapest, Hungary \\ ${ }^{2}$ Agricultural Biotechnology Center, Gödöllö, Hungary
}

\begin{abstract}
Zucchini yellow mosaic potyvirus (ZYMV) was isolated in Hungary from cucumber for the first time in 1995 and now it is widespread causing devastating epidemics in cucurbit crops.

Four isolates were chosen from different cucurbit plants collected in 1995 and 1999 and molecular variability of $\mathrm{N}$-terminal region of coat protein was studied. Hungarian isolates show lower molecular variability within themselves than with ZYMV isolates from other geographical origins. Hungarian isolates have amino acid sequences specific only to them that suggest common ancestor.
\end{abstract}

Key words: zucchini yellow mosaic virus, potyvirus.

Zucchini yellow mosaic potyvirus (ZYMV) is widely distributed potyvirus that causes important losses in a range of cucurbit crops. The apparently rapid spread of this virus in many parts of the world suggesting a very efficient transmission from plant to plant by several aphid species in a non-persistent manner (Lisa and Lecoq, 1984) and a long distance distribution via infected seeds (Schrijnwerkers et al., 1991).

ZYMV, first described in Italy (Lisa et al., 1981), belongs to the potyviruses, the largest group of plant viruses, characterized by a monopartite, positive-sense, singlestranded RNA encapsidated in flexuous, filamentous particles. The RNA is translated into a single polyprotein cleaved by three viral proteases (Reichmann et al., 1992).

In Hungary zucchini yellow mosaic potyvirus first observed in 1995 causing severe epidemics in cucurbit-growing regions (Tóbiás et al., 1996). Some zucchini yellow mosaic potyvirus were isolated and compared on test plants and ZYMV-10 strain was chosen for further characterization (Tóbiás et al., 1998).

In the past four years, many part of the country cucurbit crops were subject to severe losses due to zucchini yellow mosaic potyvirus. Several isolates have been identified among them some capable of overcoming resistance to the dominant Zym gene (Tóbiás et al., 1998). This emphasize the need for additional sources of resistance derived by either classical breeding or pathogen-derived resistance. Coat protein $(\mathrm{CP})$ mediated resistance could provide an alternative control against very destructive ZYMV. ZYMV $\mathrm{CP}$ transformation of melon is in progress. Since the effectiveness of CP resistance would depend on serological relatedness of the attacking virus the variability of ZYMV occurring in Hungary has to be studied. In fact, the $\mathrm{N}$ terminus is the only region in the entire coat protein that is unique to potyvirus and contains virus-specific and virus strainspecific epitopes (Shukla et al., 1991). Kundu et al. (1998) compared the coat protein epitopes of ZYMV and found that epitopes in the N-terminal region could differentiate among different ZYMV isolates. 
The objectives of this research were to compare sequence data of N-terminal region of $\mathrm{CP}$ to characterize the variability of zucchini yellow mosaic potyvirus in Hungarian ecosystem.

Virus isolates were from different cucurbit plants, from different region and different time. ZYMV-10 strain originated from cucumber (Békésszentandrás, 1995), ZYMV-sz6 from oilseed squash (Csabacsüd, 1998), ZYMV-sz3 from melon (Szarvas, 1999) and ZYMV-f1 from zucchini (Fertőd, 1999). The isolates were propagated by mechanical transmission in Cucumis sativus cv. Budai csemege. ZYMV-10 strain was previously characterized and partially sequenced (Tóbiás et al., 1998). ZYMV-sz6, ZYMVsz3 and ZYMV-f1 isolates were PCR amplified and cloned. Total RNA was extracted from leaves with obvious sign of disease by the method White and Kaper (1989).

Degenerate primers ZYMV CP1 (5' GTAATGCTAACCATGGGCACTCAG 3') ZYMV CP3 (5' GGGGATCCGACCTACCCTTTACTG 3') were previously designed to amplify from the second amino acid from the 5' terminal part of the coat protein to the stop codon (first amino acid of CP is constant in ZYMV because of the cleavage site Q/S). ZYMV CP3 primed single-stranded cDNA was synthesized from total RNA using the Amersham cDNA synthesis kit. Two microliters from this reaction mixture were used for PCR experiments. Amplification was performed in a volume of $50 \mu \mathrm{l}$ of PCR buffer (10 mM Tris- $\mathrm{HCl} \mathrm{pH} 9.5,2.5 \mathrm{mM} \mathrm{MgCl}, 50 \mathrm{mM} \mathrm{KCl}, 0.1 \%$ Triton X-100) containing $100 \mathrm{ng}$ each of dATP, dCTP, dGTP and dTTP, $0.1 \mathrm{nM}$ each upstream and downstream primers and $5 \mathrm{U}$ Taq DNA polymerase (Promega). Forty reaction cycles were perfomed (Perkin Elmer Cetus cycler): template denaturation at $94{ }^{\circ} \mathrm{C}$ for $15 \mathrm{~s}$, primer annealing at $55^{\circ} \mathrm{C}$ (cycles $\left.1-5\right)$ or $60{ }^{\circ} \mathrm{C}\left(6-40\right.$ cycles) for $30 \mathrm{~s}$ and DNA synthesis at $72{ }^{\circ} \mathrm{C}$ for 2 min. After electrophoresis in the 1\% agarose gel, the amplified DNA fragments were excised and isolated with Prep-A-Geneтм DNA Purification Kit from BIO RAD. Following digestion with Nco I. and BamH I, the PCR products were cloned in the pUC 19 plasmid. Nucleotide sequence of $\mathrm{N}$-terminal region of $\mathrm{CP}$ was obtained by using revers primer. Double-stranded DNA sequencing by the dideoxy chain termination method was performed using the T7 DNA polymerase (Pharmacia) according to manufacturer's instruction. Sequence analysis was performed employing University of Wisconsin Genetics Computer Group (GCG) sequence analysis software package version 9.1 and the following Web servers: http://ulrec3.unil.ch/software/BOX_form.html (Boxshade), http://bmerc-www.bu.edu/psa/(PSA), http://www.genome.ad.jp/. Sequence comparisons were performed with EMBL/GenBank databases. Multiple sequence alignments were generated using PILEUP of GCG package. CLUSTALW was used to create an input file for PHYLIP. The tree was displayed using DRAWTREE.

Comparing the amino acids of coat protein of different ZYMV isolates shows that the main differences can be found at the N-terminal part (Fig. 1). Sequences were determined for 129 nucleotides (coding 43 amino acids) of the coat protein coding region. These fragments were chosen for sequencing because the $\mathrm{N}$-terminal part of the coat protein is known to be highly variable and to contain the major virus specific epitopes, due to its localization at the surface of the virion (Shukla et al., 1988). 


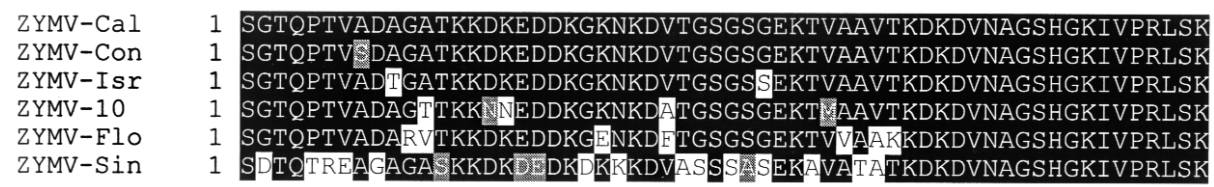

$\begin{array}{lll}\text { ZYMV-Cal } & 61 & \text { ITKKMSLPRVKGNVILDIDHLLEYKPDQIELYNTRASHQQFASWFNQVKTEYDLNEQQMG } \\ \text { ZYMV-Con } & 61 & \text { ITKKMSLPRVKGNVILDIDHLLEYKPDQIELYNTRASHQQFASWFNQVKTEYDLNEQQMG } \\ \text { ZYMV-Isr } & 61 & \text { ITKKMSLPRVKGNVILDIDHLLEYKPDQIELYNTRASHQQFASWFNQVKTEYDLNEQQMG } \\ \text { ZYMV-10 } & 61 & \text { ITKKMSLPRVKGNVILDIDHLLEYKPDQIELYNTRASHQQFASWFNQVKTEYDLNEQQMG } \\ \text { ZYMV-Flo } & 61 & \text { ITKKMSLPRVKGNVILDIDHLLEYKPDQIELYNTRASHQQEASWFNQVKTEYDLNEQQMG } \\ \text { ZYMV-Sin } & 61 & \text { ITKKMSLPRVKGSVILDIDHLLEYKPDQIELYNTRASHQQEASWFNQVKAEYDLNEQQMG }\end{array}$

ZYMV-Cal 121 VVMNGEMVWCIENGTSPDINGVWVMMDGNEQVEYPLKPIVENAKPTLRQIMHHFSDAAEA ZYMV-Con 121 VVMNGFMVWCIENGTSPDINGVWVMMDGNEQVEYPLKPIVENAKPTLRQIMHHFSDAAEA ZYMV-Isr 121 VVMNGEMVWCIENGTSPDINGVWVMMDGNEQVEYPLKPIVENAKPTLRQIMHHFSDAAEA ZYMV-10 121 VVMNGFMVWCIENGTSPDINGVWVMMDGNEQVEYPLKPIVENAKPTLROIMHHFSDAAEA ZYMV-FIo 121 VVMNGFMVWCIENGTSPDINGVWEMMDGNEQVEYPLKPIVENAKPTLRQIMHHFSDAAEA ZYMV-Sin 121 VVMNGFMVWCIENGTSPDINGVWVMMDGNEQVEYPLKPIVENAKPTLRQIMHHFSDAAEA

$\begin{array}{llll}\text { ZYMV-Cal } & 181 & \text { YIEMRNAEAPYMPRYGLLRNLRDRSLARYAFDFYEVNSKT } \\ \text { ZYMV-Con } & 181 & \text { YIEMRNAEAPYMPRYGLLRNLRDRSLARYAFDFYEVNSKT } \\ \text { ZYMV-Isr } & 181 & \text { YIEMRNAEAPYMPRYGLLRNLRDRSLARYAFDFYEVNSKT } \\ \text { ZYMV-10 } & 181 & \text { YIEMRNAEAPYMPRYGLLRNLRDRSLARYAFDFYEVNSKT } \\ \text { ZYMV-Flo } & 181 & \text { YIEMRNAEAPYMPRYGLLRNLRDRSLARYAFDFYEVNSKT } \\ \text { ZYMV-Sin } & 181 & \text { YIEMRNAEAPYMPRYGLLRNLRDRSLARYAFDFYEVNSKT } \\ & & \\ \text { ZYMV-Cal } & 241 & \text { SRLFGLDGNVATTSEDTERHTARDVNRNMHTLLGVNTMQ } \\ \text { ZYMV-Con } & 241 & \text { SRLFGLDGNVATTSEDTERHTARDVNRNMHTLLGVNTMQ } \\ \text { ZYMV-Isr } & 241 & \text { SRLFGLDGNVATTSEDTERHTARDVNRNMHTLLGVNTMQ } \\ \text { ZYMV-10 } & 241 & \text { SRLFGLDGVATTSEDTERHTARDVNRNMHTLLGVNTMQ } \\ \text { ZYMV-FIO } & 241 & \text { SRLFGLDGNVATTSEDTERHTARDVNRNMHTLLGVNTMQ } \\ \text { ZYMV-Sin } & 241 & \text { SRLFGLDGNVATTSEDTERHTARDVNRNMHTLLGVNTMQ }\end{array}$

Fig. 1. Amino acid sequence alignment for the coat protein of ZYMV isolates. Abbreviations and respective accession numbers: California strain: ZYMV-Cal: No L 31350,

Connecticut strain: ZYMV-Con: No D 00692, Florida strain: ZYMV-Flo: No D 00593, Singapure strain: ZYMV-Sin: No X 62662, Israel strain: ZYMV-Isr: No M 355095 and Hungarian strain: ZYMV-10 AJ251527

\begin{tabular}{|c|c|c|}
\hline $\mathrm{ZYMV}-\mathrm{f} 1$ & 1 SGTQPTVADAGATKKNNEDDKGKNKDA & TGSGSGEKTMA \\
\hline ZYMV-sz 6 & DDKGKNKD $z$ & SGSGEKT \\
\hline YMV-10 & EDDKGKNKD & SGEKT \\
\hline ZYMV-sz3 & GĀTKKNNEDDKGKNR̈DZ & CKTM \\
\hline YMV-Cal & TKKDKEDDKGKNKD & KTVA \\
\hline YMV-Con & ГKKDKED & KT \\
\hline sr & ADTGATKKDKEDI & KT \\
\hline 10 & 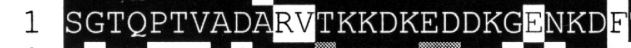 & \\
\hline- & & \\
\hline
\end{tabular}

Fig. 2. Amino acid sequence alignment for the $\mathrm{N}$ terminal of coat protein of ZYMV isolates. See Fig. 1 for abbreviation and accession numbers 


\section{Table 1}

Percentage of nucleotid sequence identity of N-terminal region of coat protein of different zucchini yellow mosaic potyvirus isolates. See Fig. 1 for abbreviation and accession numbers

\begin{tabular}{|c|c|c|c|c|c|c|c|c|}
\hline & ZYMV-Cal & ZYMV-Con & ZYMV-Flo & ZYMV-Isr & ZYMV-Sin & ZYMV-sz3 & ZYMV-sz6 & ZYMV-f1 \\
\hline ZYMV-10 & 92 & 92 & 86 & 94 & 70 & 97 & 99 & 99 \\
\hline ZYMV-Cal & & 98 & 90 & 94 & 72 & 90 & 93 & 93 \\
\hline ZYMV-Con & & & 89 & 94 & 72 & 90 & 93 & 93 \\
\hline ZYMV-Flo & & & & 88 & 69 & 84 & 86 & 86 \\
\hline ZYMV-Isr & & & & & 74 & 93 & 95 & 95 \\
\hline ZYMV-Sin & & & & & & 71 & 71 & 71 \\
\hline ZYMV-sz3 & & & & & & & 98 & 98 \\
\hline ZYMV-sz6 & & & & & & & & 100 \\
\hline
\end{tabular}

Table 1 shows the sequence identity percentage for $\mathrm{N}$-terminal part of the coat protein of different ZYMV isolates. The Hungarian isolates had nucleotide sequence identities of $97 \%$ to $100 \%$. Isolates from Hungary and ZYMV isolates from different parts of the world have sequence similarities ranging 70 to $94 \%$.

Sequence data indicate that the Hungarian isolates share more homology with the Israel strain than with any other sequenced strains. The ZYMV-Sin isolate has the lowest homology to other ZYMV isolates.

Figure 2 shows amino acid sequence identities of $\mathrm{N}$-terminal region of ZYMV isolates.

Previous studies have shown that a tripeptide sequence DAG located near the $\mathrm{N}$ terminus of the CP is required for aphid transmission (Atreya et al., 1995). This motif is highly conserved, but the context in which it is found varies considerable for different potyviruses. ZYMV-10 as an exception to other ZYMV isolates next to the DAG motif has $\mathrm{T}$ instead of $\mathrm{A}$. The Hungarian isolates at positions 16 and 17 have uniformly asparagin $(\mathrm{N})$ instead of aspartic acid (D) and lysin (K) at position 27 alanin (A) substitutes valin (V) and at 37 valin (V) changes to methionin comparing to other ZYMV strains. Apart from this ZYMV-sz3 isolate has amino acid changes at 15 and 39 position comparing to others. Hungarian isolates have amino acid sequences specific only to them as indicated in Fig. 2. Although Hungarian isolates are originated from different plants (cucumber, melon, oilseed squash and zucchini), from different regions (Békésszentandrás, Csabacsüd, Szarvas, Fertőd) and isolated at different time (1995, 1998 and 1999) they are very similar according to nucleotide and amino acid sequences. If we analyse phylogenetic relationship of N-terminal region of CP (Fig. 3) we can conclude that the Hungarian isolates clearly form a distinct branch in the phylogenetic tree and share more sequence homology among themselves than with the other strains which suggest their common origin. From this data we can predict that ZYMV-10 CP transformed plants propably will show resistance to all ZYMV isolates occurring in Hungary. 


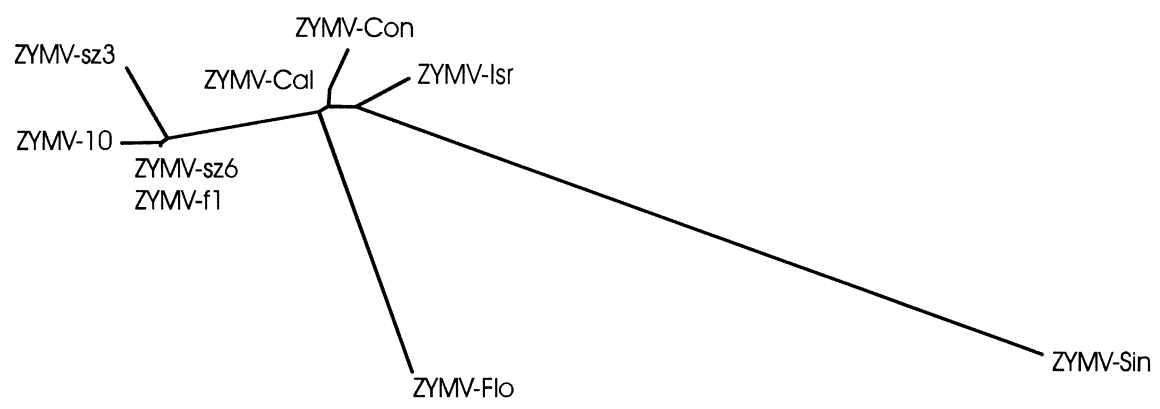

Fig. 3. Phylogenetic tree for N-terminal region of coat protein of ZYMV isolates.

See Fig. 1 for abbreviation and accession numbers

\section{Acknowledgement}

This work was supported by OTKA T 026573 grant. L. P. was supported by the Bolyai János fellowship.

\section{Literature}

Atreya, P. L., Lopez-Moya, J. J., Chu, M., Atreya, C. D. and Pirone, T. P. (1995): Mutational analysis of the coat protein $\mathrm{N}$-terminal amino acids residues involved in potyvirus transmission by aphids. J. Gen. Virol. $76,265-270$.

Kundu, A. K., Ohshima, K. and Sako, N. (1998): Comparison of coat protein epitopes of two zucchini yellow mosaic virus isolates. Acta Virol. 42, 167-173.

Lisa, V., Boccardo, G., d'Agostino, G., Dellavalle, G. and d' Aquilio, M. (1981): Characterization of a potyvirus that causes zucchini yellow mosaic. Phytopathology 71, 668-672.

Lisa, V. and Lecoq, H. (1984): Zucchini yellow mosaic virus. No. 282. In: Description of Plant Viruses. Commonw. Mycol. Ins./Assoc. Appl. Biol., Kew, England 4 p.

Reichmann, J. L., Laín, S. and Garcia, J. A. (1992): Highlights and prospects of potyvirus molecular biology. J. Gen. Virol. 73, 1-16.

Schrijnwerkers, C. C. F. M., Huijberts, N. and Bos, L. (1991): ZYMV: Two outbreaks in the Netherlands and seed transmissibility. Neth. J. Plant Pathol. 97, 187-191.

Shukla, D. D., Strike, P. M., Tracy, S. L., Gough, K. H. and Ward, C. W. (1988): The N and C termini of coat protein of potyviruses are surface-located and the $\mathrm{N}$ terminus contains the major virus-specific epitopes. J. Gen. Virol. 69, 1497-1508.

Shukla, D. D., Frenkel, M. J. and Ward, C. W. (1991): Structure and function of the potyvirus genome with special reference to the coat protein coding region. Canadian J. of Plant Pathology 13, 178-191.

Tóbiás, I., Basky, Zs. and Ruskó, J. (1996): Zucchini yellow mosaic potyvirus - a new pathogen of cucurbit plants occurring in Hungary. Növényvédelem (Plant Protection) 32, 77-79. (in Hungarian)

Tóbiás, I., Palkovics, L. and Balázs, E. (1998): Characterization of Hungarian strain of Zucchini yellow mosaic potyvirus causing severe damage on cucurbit plants. Növényvédelem (Plant Protection) 34, 613-616. (in Hungarian)

White, J. L. and Kaper, J. M. (1989): A simple method for detection of viral satellite RNAs in small tissue samples. J. Virol. Methods 23, 83-94. 